\title{
自由曲面のポイント計測に適したレーザスタイラスの機上走査制御*
}

\author{
中川平三郎** 廣垣俊樹*** 梶 章宏 $^{\dagger} \quad$ 喜田義宏 $^{\dagger}$ 垣野義昭 ${ }^{\dagger}{ }^{\dagger}$ \\ In-situ Suitable Controlled Scan of Laser Stylus for Point Measuring of Free Surface \\ Heisaburo NAKAGAWA, Toshiki HIIROGAKI, Yoshihiro KAJI, \\ Yoshihiro KITA and Yoshiaki KAKINO
}

\begin{abstract}
The present report describes the suitable in-situ scan of a laser stylus for point measuring of free surface with a machining center. The attempts were made to improve the reliability of the measuring accuracy using numerical control function of G02 and G03. That is, we proposed a new measuring method that the laser stylus was scanned around a measuring point on the free surface. The experiments were done to measure the ground surfaces and the end-milled ones by this scanning method. As a result, it is clear that there is proper radius to scan a laser stylus according to surface roughness
\end{abstract}

Key Words : laser stylus, in-situ, point measuring, free surface, machining center, numerical control, accuracy

1. 緒言

マシニングセンタを用いて自由曲面形状を有する金型を加工 することが多い．加工された自由曲面形状の計測には三次元測 定機（CMM）が用いられている.しかしながら，大型の金型 等の测定には大型の三次元測定機が必要になること.さらに大 型の重量物の着脱に手間がかかることなどの問題点がある. そ こで大型の金型を中心にマシニングセンターの機上で三次元自 由曲面形状の計測ニーズが増大している。

加工後の形状計測には先端が球状のタッチプローブを用いる ことが多い. しかしながら加工䛊差を有する三次元自由曲面形 状を対象にした計測では, プローブ球の工作物との接蚛箅所を 正確に特定することが難しいのが現状である. 一方，スピンド ル軸に同軸でレーザ光を照射するレーザスタイラスではプロー ブ球半径補正に該当する処理が必要ない利点を有するため, マ シニングセンターの機上測定に適したレーザスタイラスの開発 が行なわれてきた1)2.これらの報告では金型など金属加工面に おいても受光素子の配置を工夫するなどスタイラス自体のハー ド面の改良により計測精度の改善を実現している.これらハー ド面の改良手法では, レンズ光学系の複雑化や受光素子数の增 大などの問題点を残しているものと考えられる.

そこで本報では，汎用的なレーザスタイラスを用いたマシニ ングセンターの機上での三次元自由曲面の計測を対象とし、ソ フト的な機能である数值制御機能を活用した自由曲面のポイン ト形状の計測に適したスタイラスの走査制御法を考案したので 以下にその詳細を述べる.

\footnotetext{
* 原稿受付平成 15 年 3 月 3 日

** 正会貝 滋賀県立大学工学部（彦根市八坂町 2500)

*** 正会員 同志社大学工学部 (京田辺市多々羅都谷 1-3)

+ダイジェット工業(株) (大阪市平野区加美 2-1-18)

+ 正会員大阪工業大学 (大阪市旭区大宮 5:16-1)

H+ 正会員京都大学大学院工学研究科 (京都市左京区吉田本町)
}

\section{2. 自由曲面計測における問題点}

\section{1 タッチプローブの問題点とその解決方法}

図1(a)は球状の先端部を有するタッチプローブが計測物に接 触している状熊を示している. 従来の CMM やマシニングセン タ一機上での形状計測では, 先端球の接触を検知して対象工作 物表面の形状を測定している，その場合，図に示されるように 接触点の $\mathrm{x}, \mathrm{y}, \mathrm{z}$ 座標とプロープ中心の $\mathrm{x}, \mathrm{y}, \mathrm{z}$ 座標が異なるため, 接触検知後にプローブ球半径補正と呼ばれるデータ処理が必要 となる. 2 次元や 2.5 次元形状を計測する場合にはその処理は 容易であるが，三次元自由曲面形状を対象にする場合には，正 確な処理は極めて困難となる，一方，マシンングセンターの主 軸に同軸にレーザを照射するレーザスタイラスを用いると，ス ピンドル軸の中心が計測位置と一致する（図 1(b)参照）ため, 数学的処理は極めて容易となる. そこで本報では，マシニング センターの主軸とレーザ光の光軸を一致させて計測が可能であ る散乱光を榆出するタイプの三角測量法の原理を利用した市販 品のレーザスタイラス（キーエンス社製 LT8110）を用いる. その主な仕様を表 1 に示す.

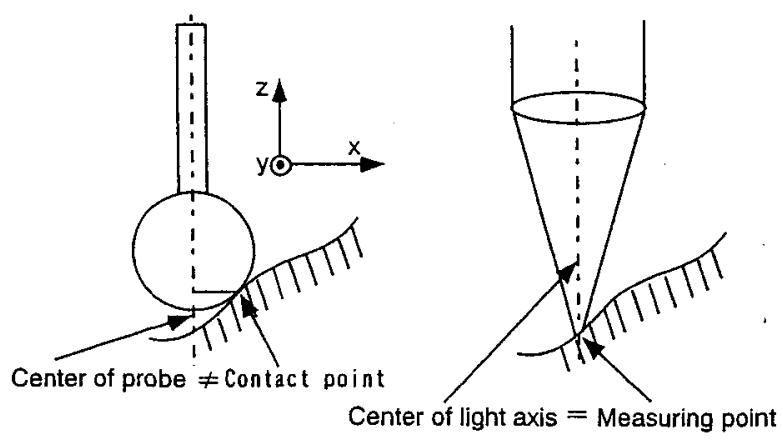

(a) Conventional probe

(b) Laser stylus 
Table 1 Specification of laser stylus

\begin{tabular}{c|c}
\hline Measuring range & $\pm 5 \mathrm{~mm}$ \\
\hline Basic operating distance & $30 \mathrm{~mm}$ \\
\hline Laser source & Semiconductor laser \\
\hline Wave length & $0.67 \mu \mathrm{m}$ \\
\hline Output & $0.95 \mathrm{~mW}$ \\
\hline Spot diameter & $30 \mu \mathrm{m}$ \\
\hline Resolution & $0.1 \mu \mathrm{m}$ \\
\hline
\end{tabular}

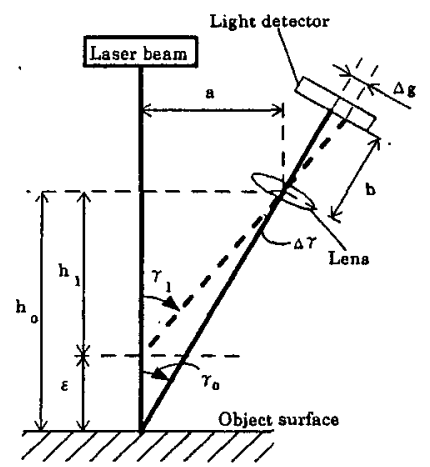

Fig. 2 Measuring principle of laser stylus

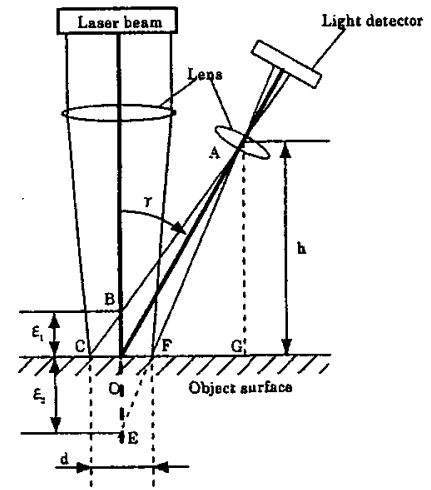

Fig. 3 Error due to laser spot diameter

\section{2 レ一ザスタイラスの原理およひ問題点}

図 2 に三角測量法の原理を利用したレーザスタイラスの測定 原理を示す．測定物の表面に照射されたレーザ光は表面で散乱 光を発生する.その散乱光の一部をレンズで集光した後に受光

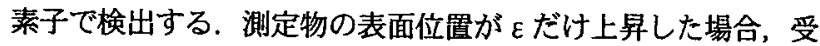


移動する.すなわち， $\Delta \mathrm{g}$ より測定表面の高さ方向の移動距離 が判明する3)，この場合，測定物の表面に照射されているレー ザのスポット径は無限小を仮定している．しかしながら実際に 照射されるレーザ光は有限のスポット径である.そこでスポッ 卜径が有限であることに起因する測定誤差を考える. 照射され るレーザの光強度はガウス分布をしており光軸の中心で最大強 度である，通常は光強度が最大である光軸中心から散乱された 光が受光素子上でも最大強度を示す．しかしながら金属などの 表面では，粗さによる凹凸や油膜やゴミなどの表面付着により 必ずしも光軸中心で最大の散乱光を発するとは限らない. 例え ば図 3 の C 点 (スポット径の端) で散乱光が最大強度となる場 合, 受光素子からみれば光軸中心の反射位置は B 点と認識する ため， $\varepsilon_{1}$ だけ実際より高い位膡と感知する. また図 3 の F 点

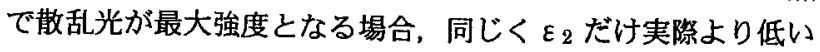
位置と感知する. そこで, 本スタイラスのレーザスポット径に

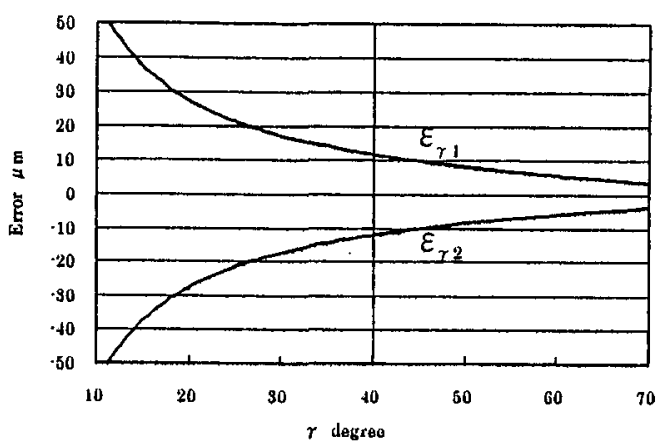

Fig. 4 Influence of tilting angle $r$ on maximum error
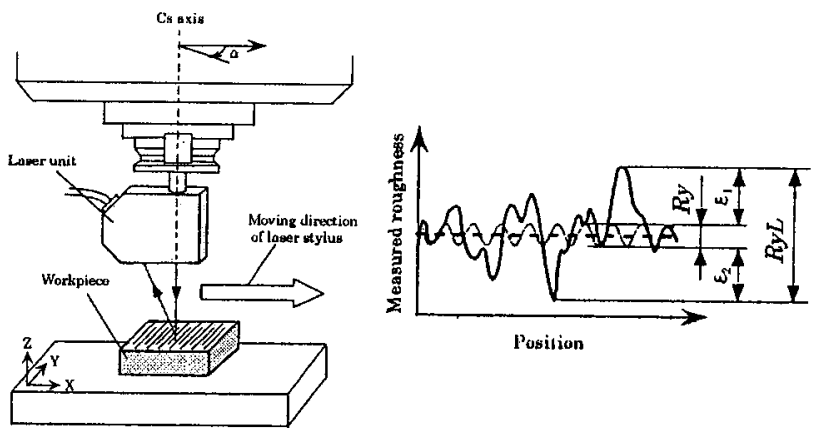

Fig. 5 Scanning for ground surface with laser stylus

おいて受光素子と光軸のなす傾き角 $\gamma ， \varepsilon_{1}$ および $\varepsilon_{2}$ の関係を 計算した結果を図 4 に示す．図より， $\gamma$ を大きくすると誤った 位置を検知する幅（ $\varepsilon_{1}$ と $\varepsilon_{2}$ の和）は小さくなり，測定精度が 向上することがわかる. しかしながら， $\gamma$ を大きくすると受光 素子に達する散乱光の絶対光量が減少し，光量不足となる. 本 報で使用したレーザスタイラスは $\gamma=40^{\circ}$ であるので，図より スポット径が有限であることに起因する測定誤差は土 $12 \mu \mathrm{m}$ 程度（全振幅で約 $24 \mu \mathrm{m}$ ）となることがわかる，以上より，金 属表面の測定時には，测定面の表面粗さや油膜などの影響によ り必ずしも光軸中心からの散乱光が最大強度を示すとは限らな いために, 最大で士 $12 \mu \mathrm{m}$ 程度の測定誤差が生じる可能性があ ることがわかった。

\section{3.レ一ザスタイラスの特性評侕}

\section{1 表面粗さの影整}

本研究で使用したレーザスタイラスの特性を実際に評価する 図 5 に測定方法を示す．立形マシニングセンタ（安田工業製 YBM850V）の主軸にレーザスタイラスを取付け，研削加工さ れた加工面上を走査した．また後述するマシニングセンターの 運動精度に起因する誤差を避けるために，走査時の送り速度は 極低速 $(1 \mathrm{~mm} / \mathrm{min})$ で実験した. 計測対象面の加工条痕に対す る受光素子の方向の影響を評価するため,レーザスタイラスの 送り方向に対して受光素子が後方にある場合を基準として，時 計回りにスタイラスを回転させた角度を $\alpha$ と定義する. また測 定対象とした研削加工面の最大粗さを $R y$ とし，レーザスタイ ラスで測定した出力の全振幅を $R y L$ と定義する（図 5 参照）. $R y$ と $R y L$ との差がスポット径が有限であることに起因する $\varepsilon_{1}$ および $\varepsilon_{2}$ と考えられる. 最大粗さ $R y$ が異なる種々の研削およ び研磨加工面（材質は SUJ2，硬さ HRC60）に対し， 


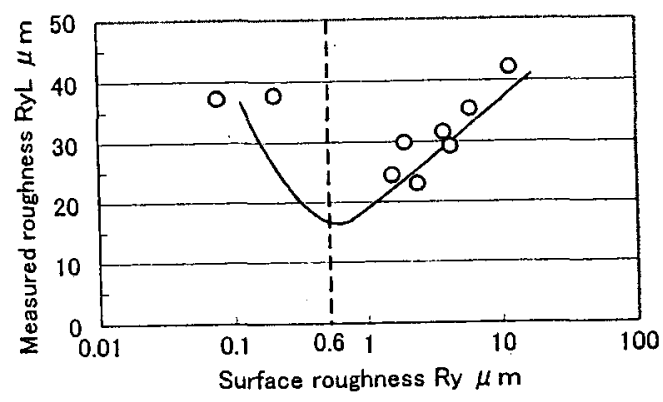

Fig. 6 Surface roughness and obtained results by scanning

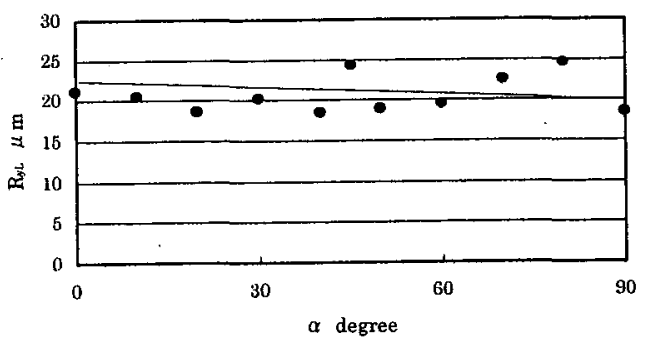

Fig. 7 Influence of detector angle $\alpha$ on $R y L(R y=3.2 \mu \mathrm{m})$

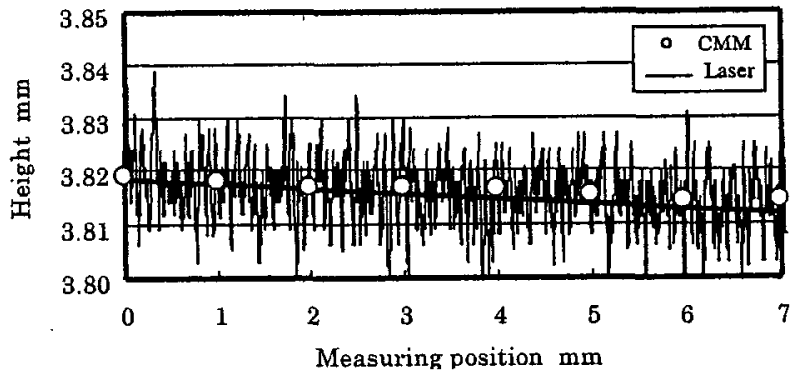

Fig. 8 Comparing measured results by CMM with ones by laser stylus

$\left(R \mathrm{y}=3.2 \mu \mathrm{m}, \alpha=0^{\circ}\right)$

レーザスタイラスで走査して得た全振幅 $R y L$ を図 6 に示す. 走 査対象の加工面の最大粗さ $R y$ が小さくなると，得られる全振 幅 $R y L$ も幾分減少する傾向にある．しかしながら，加工面の最 大粗さがレーザの波長 $(0.67 \mu \mathrm{m})$ 以下になると,レーザ光の 千渉のため再び得られる全振幅が增大する傾向にある.

\section{2 加工条痕と受光素子の方向}

本節では研削加工の条痕に対する受光素子の方向の影響を 調べる. 図 $7 に$, 図 5 の定義に従い研削加工の条痕に対して計 測時の受光素子の方向を変化させた状態で $R y L$ を計測した結 果である. 研削条痕に対して受光素子の方向を変えることで, 幾分は $R y L$ を小さく抑えることが可能である場合も存在する が，その効果は小さいことがわかる，また一般に，ボール状砥 石やボールエンドミルなどで自由曲面形状は仕上げられており， 表面に残る条痕の方向は複雑になると考えられ, 条痕の方向に 適応して受光素子を制御するようなことも実用的には不可能で ある。

\section{3 三次元測定機による計測結果との比較}

研削加工された緩斜面をレーザスタイラスで測定した結果と その斜面を CMM で測定した結果（図中の○点）の比較を図 8 に示す、また図中の直線はレーザスタイラスで測定した点を最 小二乗法で近似したものである. 前節までの結果でも明らかよ うに，レーザスタイラスによる测定では表面性状の影響により 全振幅は大きな值を示している. しかしながら, そのデータの
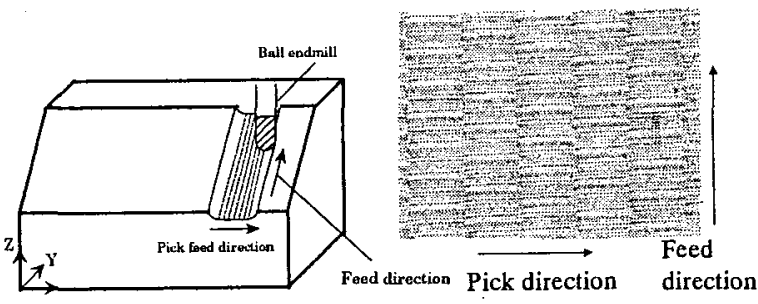

Fig. 9 Surface formed by ball end-mill

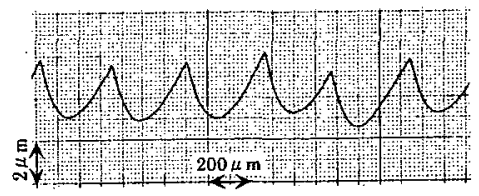

(a) Pick feed direction

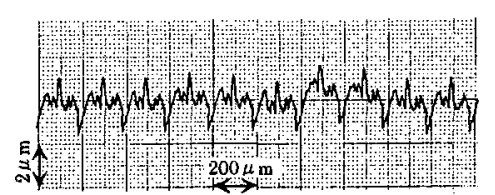

(b) Feed direction

Fig. 10 Surface profile curve formed by ball end $\cdot$ mill



(a) $\alpha=0^{\circ}$



(b) $\alpha=90^{\circ}$

Fig. 11 Influence of detector angle $\alpha$ on measured results

最小二乗近似線はほぼ CMMによる測定結果と一致することが わかる.この結果は, レーザスタイラスを用いて取得したデー タは真值を中心にランダムに変動することを示している.すな わち，ある程度の走查距離を確保し，そのデータを平均化する ことで取得したデータは真值に収束し，測定の信頼性が向上す ることがわかる.

\section{4 ボールエンドミル加工面に対する計测}

自由曲面形状はボールエンドミルを用いて加工される場合が 多い.そこでボールエンドミル(2枚刃, 工具の先端半径 $5 \mathrm{~mm}$, 主軸回転数 $7200 \mathrm{rpm}$, 送り量 $0.1 \mathrm{~mm} /$ tooth, ピックフィード $0.35 \mathrm{~mm}$, 軸方向切込み $1 \mathrm{~mm}$ )を用いて図 9 に示すように $45^{\circ}$ 傾斜面を（材質は SNCM439，硬さ HRC40）加工し（図中に は加工面の光学顕微鏡写真も合わせて示す)，その加工面を 


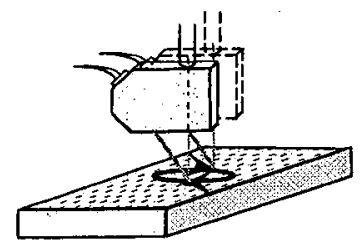

Fig. 12 Circular scanning of laser stylus

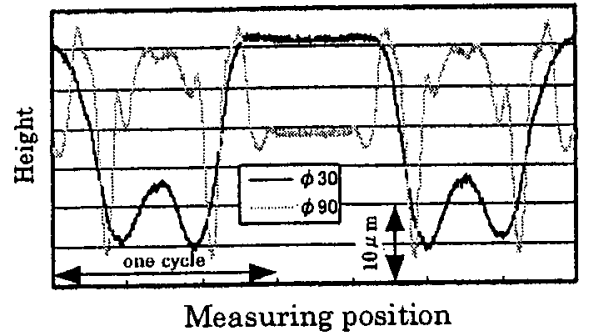

Fig. 13 Measured results by C.W and C.C.W scanning

レーザスタイラスで計測する. また図 10 には加工面の粗さ曲 線を示す. 図 10 より加工面の最大粗さは $2 \mu \mathrm{m}$ 程度であり, 実際の金型における仕上げ加工に相当することがわかる.また ピックフィード方向の山間隔は約 $350 \mu \mathrm{m}$ であり，CL のピッ ク間隔と一致している. 送り方向の山間隔は約 $200 \mu \mathrm{m}$ であり, これは工具刃先の振れの影響が現れたものと考えられる. 図 11 にレーザスタイラスをピックフィード方向に走査して得られた 結果を示す. 走查方向に対する受光素子の方向 $\alpha=0^{\circ}$ および $90^{\circ}$ で測定し結果である. また図には加工面の粗さ曲線を合わ せて示してある. 図より受光素子の方向により測定結果の波形 に違いがあるが, 最大粗さ $2 \mu \mathrm{m}$ 程度のボールエンドミル加工 面に対しても両者とも土 $10 \mu \mathrm{m}$ 以上の変動がみられることが わかる.

\section{4. 円運動機能を用いた走查法の提案}

\section{1 レーザスタイラスの走查方法}

自由曲面のポイント測定において測定距離を確保する手法と して，取得したい測定ポイントを中心にレーザスタイラスをマ シニングセンタの数值制御機能を用いて円運動 (G02 またはG 03 機能）で走查する手法を提案する．図 12 は研削加工面上を 円運動で走查している例を示す。図 13 は 1 回転円運動で測定 した後に，逆方向の円運動で元の位置にレーザスタイラスをも どした時の測定結果を示す. 円運動の運動直径 $\phi 30 \mu \mathrm{m}, \phi 90$ $\mu \mathrm{m}$ とした場合とも，正回転時と逆回転時で極めて高い湘定結 果の再現性が確認できる.したがって，以後は円運動で一回転 して得られた測定結果の平均値を,その中心位置の高さとする.

\section{2 走龺する円进勤の径の決定方法}

レーザスタイラスを走査する円径が小さいとデータを取得で きる走査距離が減少する一方，円径が大きいと取得したい測定 ポイントから離れた位置でデータを取得することになる，そこ で, 測定対象となる加工面性状に応じた適切な走査円径を調べ る. 図 14 は研削加工面 (最大粗さ $6 \mu \mathrm{m}$, 平均山間倩 $30 \mu \mathrm{m}$ ) に対して测定時の走査円径と CMMを用いて同一の点の位固を 検出した結果の差を示す，図より，加工面粗さの平均山間隔以 上の走查円径を確保することで, 十分な測定精度が得られるこ とがわかる. 図 15 は水平にしたボールエンドミル加工面（送 り量 $0.02 \mathrm{~mm} /$ tooth）に対して, 測定時の走査円径と CMM を



Fig. 14 Relationship between circular diameter and error (Ground surface)

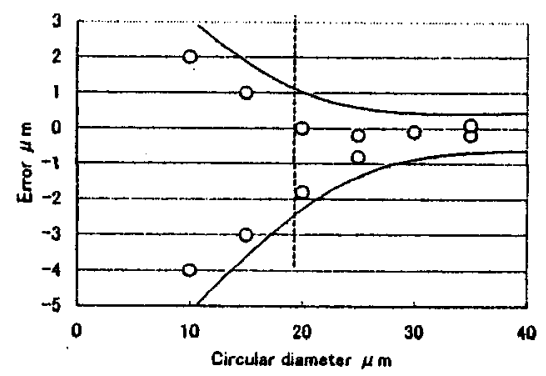

Fig. 15 Relationship between circular diameter and error (Ball end-milled surface)

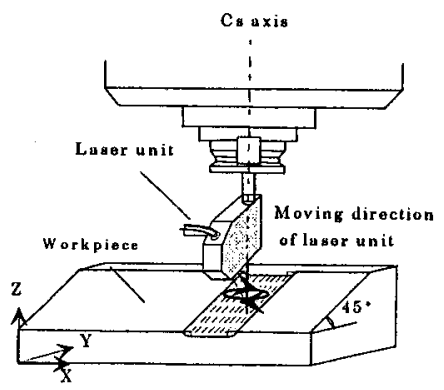

Fig. 16 Scanning for slant surface



Fig.17 Relationship between circular diameter and error (Slant surface formed by ball end-mill)

用いて測定した結果の差を示す．図より，一州当たりの送り量 $(20 \mu \mathrm{m})$ 以上（加工面の凸間隔）の走查円径を確保すること で, 表面粗さや油膜などの外乱に対するロバスト性も確保され， 十分な測定精度が得られることがわかる。

\section{3 急㑯鈄面に対する剆定洁果}

急傾斜面に対して測定する場合， $\mathrm{X} \cdot \mathrm{Y}$ 平面内で円運動する手 法（同時 2 軸制御運動）と，测定点の接平面に平行な面内で円 運動する手法（同時 3 軸制御運動）が考えられる.しかしなが 


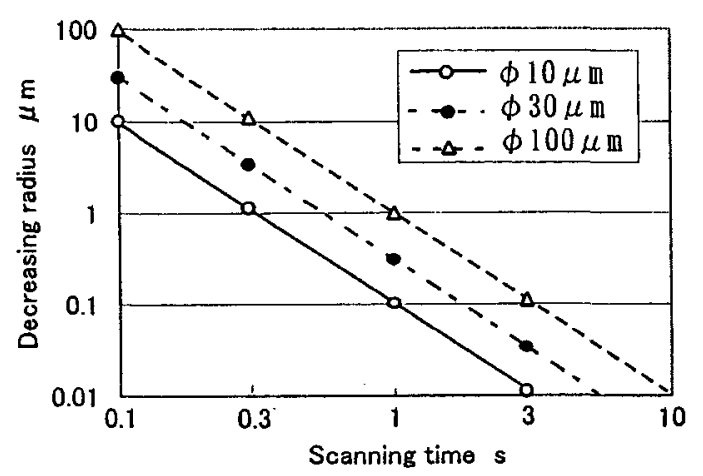

Fig. 18 Influence of scanning time for measuring on decreasing radius in scanning

ら同時 3 軸制御運動すると $\mathrm{Z}$ 軸にも運動が加わることになる. すなわち、、シニングセンタ自体の Z 軸の運動誤差も湘定誤差 に含まれ好ましくないと考えられる. そこで図 16 に示すよう にX-Y 平面内の円運動で, ボールエンドミルで加工された $45^{\circ}$ 傾斜面（送り量 $0.1 \mathrm{~mm} /$ tooth）の測定を行った. 図 17 に測定 時の走查円径と CMM を用いて湘定した結果の差を示す. 図よ り，急傾斜面の測定においても一刃当たりの送り量以上の走査 円径を確保することで CMM で測定した結果との差は $2 \mu \mathrm{m}$ 以 内に収束しており，十分な測定精度が得られることがわかる. また本手法は，傾斜面だけでなく多様な測定対象にでもレンズ 光学系などのハードの変更することなく適当な走查円径にする ことで敏速に対応できる可能性があると考えられる。



前節までの結果より，提案したマシニングセンタ機上で円運 動（G02 またはG03 機能）機能を利用した計測手法の有効性 が示された. 本節では測定時間の観点からその実用性を考察す る.

計測時間を短縮するために円運動時の送り速度を上げる必要 がある一方で, 送り速度の增大はサーボ系の追従遅れによる円 弧補間運動時の半径減少を生じさせる4). 加減速パターンが直 線で指示されている場合, 指令半径 $R$ と実際の運動半径の差 $\Delta$ $R$ 江

$$
\left.\Delta R=\left\{\left(T \mathrm{~s}^{2} / 24\right)+\left(T \mathrm{p}^{2} / 2\right)\right\} \times(F / 60) 2\right\} / R
$$

となる5)，Fは指令送り速度 $(\mathrm{mm} / \mathrm{min}) ， T s$ はスムージング回路 の時定数( $\mathrm{s}) ， \mathrm{~T}$ は位置ループ時定数( $\mathrm{s}$ )である.ここで設定值


して一周の走查に要する時間と半径减少量の関係を調へた結果 を図 18 に示す. 例えば，走查円径を $\phi 100 \mu \mathrm{m}$ とても走查時 間を $3 \mathrm{~s}$ （指令送り速度は $6.3 \mathrm{~mm} / \mathrm{min}$ ）確保すれば, 半径減少 量は $0.1 \mu \mathrm{m}$ 程度となる. 1 ポイントの測定が $3 \mathrm{~s}$ 程度ならば, 通常の接触式プローブによる測定と測定時間において大差ない とものと考えられる. またリニアモータを応用した工作機械な どサーボ系の追従性の改善は今後も進むと考えられ，その結果， 測定時に用いることのできる送り速度も向上すると考えられる。 したがって，本手法は測定時間の観点からも十分に実用性があ るものと考えられる. また, 円運動させることで測定したいポ イントから幾分の離れた位直でデータを取得することになるが， 従来の接触式の測定で用いられているタッチプローブ球の直径 が $\phi 2000 \mu \mathrm{m}$ 程度であるのに対し, 円運動の直径は大きくても $\phi 100 \mu \mathrm{m}$ 以下に押さえることが可能であり，本走查法は自由 曲面の測定に有利になる場合が多いと考えられる。また測定域 の近くにエッチ部が存在し十分な走查円径が確保できない場合 には，走查を円から楕円等に変更することである程度の対応が 可能と考えられる.

\section{5. 結言}

三角測量法の原理に基づいたレーザスタイラスを用いたマシ ニングセンターの機上での三次元自由曲面の計測を想定し，数 值制御機能を活用した自由曲面のポイント形状の計測に適した スタイラスの走查制御法を検討した結果，次の結論を得た.

(1) ポイント測定において，测定したいポイントとレーザの光 軸中心を一致させても，金属などの表面では粗さに上る凹凸 や油膜やゴミなどの表面付着により必ずしも光軸中心からの 散乱光が最大強度を示すとは限らない，そのための誤差が生 じて測定の信頼性が低下する.

（2）レーザスタイラスを用いて加工面を走查して取得したデー 夕は，真值を中心にランダムに変動する．したがって，ある 程度の走查距離を確保しそのデータを平均化することで取得 したデータは真値に収束し，測定の信頼性が向上する

（3）走查距離を確保する手法として，取得したい測定ポイント を中心にレーザスタイラスをマシニングセンタの数值制御機 能を用いて円運動（G02 または G03 機能）で走查する手法 を提案した. その結果, 測定における走查円の直径として加 工面粗さの平均山間隔以上を確保することで，十分な測定精 度が得られることがわかった.

(4) 本手法の測定時間は主に測定時の円運動の送り速度により 決定される. 測定に使用できる送り速度はマシニングセンタ のサーボ系の追従遅れによる円弧補間運動時の半径減少によ り制約されるが, 現在のマシニングセンタでも 1 ポイントの 測定に要する時間は短く(例えば $3 \mathrm{~s}$ 程度)，測定時間は実用 上問題ないことがわかった.

また本研究の一部には，日本学術振興会・科学研究費・基 板研究 C2（14550103）を用いた．記して感謝いたします.

1）青山英樹，山崎和雄, Kee Sein Lee, 澤田雅二 : 非接触型傾き • 距離検出センサによる三次元形状の自律高速計測に関する研究 (第 1 報) マルチビーム投光型傾き・距離同時連続検出センサ用 エレメントの設計，精密工学会誌，60，6(1994)847.

2) 㝡朝扸, 三好隆志, 高谷裕浩, 高橋哲, 梁田和雄 : 金型加工曲 面の光リング式 $3 \mathrm{D}$ 形状計測センサの開発研究（第 1 報）金属面 の光散乱シュミレーションとその検証，精密工学会誌，65, 11 (1999) 1668.

3）金田一 : 三角測量法によるレーザ一式変位計の高精度化一測定 面の影響について，計測自動制御学会論文集，27，8(1991)853. 4) 垣野義昭, 井原之敏, 中津善夫, 米谷光雄, 手嶋健夫 : NC工作 機械の運動精度に関する研究（第 4 報）円弧補間時の半径減少の NC 補正, 精密工学会誌, 54, 6 （1988）1113.

5) 三菱電機 : 三菱数值制御装置 MELDAS300 シリーズ プログラ ミング説明書, (1987) 29. 